Syntax Fusion : Jurnal Nasional Indonesia

e-ISSN : 2775-4440

Vol. 1, No. 9, September 2021

\title{
UPAYA MENINGKATKAN HASIL BELAJAR SISWA KELAS VI SD NEGERI 1 TELUK BETUNG DALAM MENYELESAIKAN SOAL CERITA MELALUI MODEL PEMBELAJARAN TUTOR SEBAYA DALAM KELOMPOK KECIL
}

\section{Rakila}

SDN 1 Teluk Betung

Email: rakila684@gmail.com

\begin{abstract}
Abstrak
Motivasi dari penelitian ini adalah banyak siswa yang tidak mengerti dan merasa kesulitan untuk menghitung luas bangun yang direncanakan dan bentuk yang sebenarnya, terutama pada saat menyelesaikan soal cerita pada denah berskala. terus mencari solusi untuk masalah tersebut.Cara yang baik dan benar. cerita. Dengan cara ini, nantinya siswa akan benar-benar memahami cara menyelesaikan masalah dengan benar, yaitu dari pertanyaan yang diketahui, ditanyakan, dan dijawab, akhirnya siswa dapat menuliskan hasil akhir dari masalah tersebut. Tujuannya untuk meningkatkan hasil belajar siswa kelas VI SD Negeri 1 Teluk Betung Kabupaten Kalaw, dan memecahkan masalah yang berkaitan dengan membaca gambar atau denah skala melalui tutor sebaya kelompok.

Objek penelitian ini adalah siswa kelas 19 SD Negeri 1 Teluk Betung.Pengumpulan data dilakukan melalui observasi dan pengujian, dan analisis data menggunakan analisis deskriptif kuantitatif dan kualitatif. Penelitian dilakukan dalam tiga (tiga) siklus. Hasil penelitian menunjukkan bahwa 11 siswa memiliki nilai di bawah 6,5 pada ujian putaran pertama, dengan rata-rata 6,32. Meskipun tingkat ketuntasan belajar baru mencapai 42\%, fakta ini menunjukkan bahwa hasil belajar masih sangat rendah. Pada pelaksanaan siklus II, 7 siswa mendapat nilai kurang dari 6,5, dan 12 siswa mendapat nilai lebih dari 6,5. Nilai rata-rata yang diperoleh adalah 7,26. Oleh karena itu, tingkat keberhasilan siswa sangat meningkat. Pada pelaksanaan siklus III, hanya 4 siswa yang mendapat nilai kurang dari 6,5, sedangkan 15 siswa mendapat nilai lebih dari 6,5, nilai rata-rata siklus III adalah 8,11, dan tingkat ketuntasan mencapai $79 \%$.
\end{abstract}

Kata Kunci: Hasil Belajar, Soal Cerita, Tutor Sebaya, Kelompok Kecil

\section{Pendahuluan}

Kenyataan yang ada pada saat ini, masih banyak siswa sekolah dasar yang belum mempunyai keterampilan membaca gambar atau denah berskala. Masih 
banyak juga siswa yang belum memahami cara menyelesaikan soal-soal cerita yang berhubungan dengan satuan panjang dan luas pada denah berskala. Hal ini dapat dilihat setiap kali siswa diberi soal tentang denah berskala, sebagian siswa masih mengalami kesulitan. Kemauan dan kemampuan siswa dalam menyelesaikan soal matematika tidaklah menyenangkan bagi guru. Seringkali semua soal matematika dianggap sulit baginya. Maka minat siswa perlu dibangkitkan dalam proses pembelajaran matematika dengan variasi belajar yang menarik, agar nantinya siswa dapat menyelesaikan soal dengan benar. Siswa diajak belajar di luar kelas untuk dikenalkan pada lingkungan sekitar sebagai obyek pembelajaran. Misalnya siswa diberi tugas melalui kelompok-kelompok kecilnya untuk mengukur halaman sekolah. Dengan dipandu tutor sebayanya, kemudian siswa diharapkan mampu menggambar halaman sekolah dengan denah berskala. Siswa juga dituntut untuk bisa menyelesaikan soal-soal cerita yang berhubungan dengan satuan panjang dan luas, sesuai dengan langkah-langkah menyelesaikan soal cerita yangbenar.

Proses pembelajaran matematika pada pokok bahasan tersebut selama ini belum memperoleh hasil yang memuaskan, rata-rata berkisar 5,8. Nilai tersebut perlu ditingkatkan melalui penerapan atau praktik langsung pada benda-benda konkret dan siswa sering diberi latihan soal-soal cerita yang berhubungan dengan kehidupan sehari-hari.Siswa diberi cara atau langkah-langkah menyelesaikan soal cerita dengan benar. Serta diberi pengertian bahwa antara luas pada denah berskala, berbeda dengan luas sebenarnya.

Sehubungan dengan itu dari sekian banyak soal-soal latihan yang diberikan guru,pada bagian ini masih banyak siswa yang belum memahami dan mengalami kesulitan untuk menghitung luas bangun pada denah dengan bangun sebenarnya, terutama dalam menyelesaikan soal cerita pada denah berskala. Maka peneliti mempunyai alasan untuk terus mencari cara-cara yang baik dan benar dalam menyelesaikan soal cerita. Dengan demikian, nantinya siswa benar-benar memahami cara menyelesaikan soal cerita dengan benar, yakni dari apa yang diketahui, apa yang ditanyakan dan apa jawaban soal tersebut, yang akhirnya siswa mampu menuliskan hasil akhir soaltersebut.

Menurut A. Kereng (2003:6) "Keberhasilan anak dalam belajar sangat dipengaruhi beberapa faktor seperti guru, alat atau fasilitas, sarana dan prasarana pendidikan, juga lingkungan sekitar, meskipun sifatnya hanya sebagai pendukung atau penunjang dalam pengembangan potensi yang dimiliki oleh siswa yang bersangkutan. Sedangkan faktor yang paling menentukan adalah kemampuan dan kemauan siswa itu sendiri”.

\section{Metode Penelitian}

Penelitian tindakan kelas yang berjudul "Upaya Meningkatkan Hasil Belajar Siswa Kelas VI SD Negeri 1 Teluk Betung Kecamatan Karau Kuala dalam Menyelesaikan Soal Cerita tentang Membaca Gambar atau Denah Berskala Melalui Model Pembelajaran Tutor Sebaya dalam Kelompok Kecil”, ini dilaksanakan di SD 
Negeri 1 Teluk Betung Kecamatan Karau Kuala, yang beralamat di desa Teluk Betung, sebenarnya letak SD cukup strategis karena berada di pinggir Sungai besar yaitu Sungai Barito yang lalu lintasnya setiap saat cukup ramai, apalagi pada pagi hari. Namun kondisi siswanya kurang menunjang dan cukup memprihatinkan, karena semua siswanya berasal dari satu desa.Untuk itu diperlukan kemampuan guru yang dapat menciptakan suasana sekolah yang menyenangkan bagi siswanya.Terutama guru yang mampu membawa anak-anak ke perubahan yang berarti.Maka kolaborasi antar teman sejawat sangat diperlukan demi tercapainya penelitian tersebut.

Subyek yang diteliti adalah siswa kelas VI tahun pelajaran 2018/2019, dengan jumlah 19 siswa, yang terdiri dari 8 siswa laki-laki dan 11 siswa perempuan. Mengajar dengan siswa yang rata-rata kurang dari 30 siswa, sebenarnya bisa memudahkan guru dalam mengamati siswa secara individual, namun karena kondisi siswa berasal dari masyarakat ekonomi lemah dan kurang perhatian dari pihak orang tua terhadap anaknya dalam bidang pendidikan, maka diperlukan sosok guru yang bias bertindak sebagai teman dalam belajar serta koordinasi yang baik antara sesama guru sangat diperlukan untuk meningkatkan hasil belajar siswa.

Penelitian tindakan kelas ini merupakan siklus yang dirancang dalam tiga siklus.Setiap siklus ada empat tahapan yaitu perencanaan, tindakan, pengamatan, dan refleksi. Tahapan tersebut disusun dalam siklus dan setiap siklus dilaksanakan sesuai perubahan yang ingin dicapai.

\section{Hasil Dan Pembahasan}

\section{A. Pelaksanaan Siklus I}

1. Perencanaan

Pada siklus ini disampaikan materi tentang cara membaca gambar atau denah berskala yang dikaitkan dengan kehidupan sehari-hari. Kemudian siswa diberi juga materi tentang cara menggambar berskala pada bangun datar dengan contohcontohnya yang disajikan dengan lingkungan sekolah sebagai objek pembelajaran.

Pada rencana pembelajaran siklus I ada dua tujuan yang ingin dicapai setelah proses pembelajaran selesai dilaksanakan. Yang pertama, setelah siswa memperhatikan pembelajaran guru tentang cara membaca gambar atau denah berskala dengan dipandu dengan tutor sebayanya siswa dapat membaca gambar atau denah berskala. Yang kedua, setelah siswa memperhatikan penjelasan guru tentang cara menggambar berskala pada bangun datar dengan dipandu tutor sebayanya siswa dapat menggambar berskala pada bangun datar.

Dalam pembentukan kelompok disesuaikan dengan jumlah siswa yang ada. Jumlah siswa dalam penelitian ini ada 19 siswa. Maka setiap kelompok berjumlah 6 orang siswa, ditambah 1 kelompok yang beranggotakan 7 orang siswa. Jadi kelompok kecil yang ada dalam satu kelas terdiri dari tiga kelompok.

Pembentukan kelompok pada siklus I dengan memilih anggota kelompok secara acak (urutan tempat duduk). Hal ini memungkinkan siswa belajar bersama anggota kelompoknya tidak pilah-pilih teman. Hanya dalam kelompok tersebut tetap 
dipilih siswa terpandai untuk dijadikan pemandu dalam menyelesaikan tugastugasnya.Dengan kata lain siswa terpandai dalam kelompok itu berkedudukan sebagai tutor sebaya.

Untuk lebih mengenal siswa pada objek pembelajaran secara konkret, penelitian mengajak siswa ke luar kelas, mengukur halaman dengan kelompok kecilnya dan menggambar dalam bentuk denah atau gambar berskala. Dengan menggunakan alat-alat yang dibutuhkan seperti penggaris $(1 \mathrm{~m})$ atau meteran yang lain. Semua anggota kelompok aktif dalam melaksanakan pengukuran, kemudian mendiskusikan dalam kelompoknya dengan dipandu tutor sebayanya. Hasilnya disampaikan dalam bentuk laporan dan salah satu melaporkan di depan kelas.

Dalam kegiatan penelitian tindakan kelas ini, peneliti mengajak teman sejawat sebagai teman atau pengamat penelitian. Hal ini dimaksudkan untuk mengetahui sejauh mana keberhasilan siswa dalam menyelesaikan soal cerita, pada pokok bahasan membaca gambar atau denah berskala dalam kelompok kecil dengan dipandu tutor sebayanya, pengamat bertugas mencatat hal-hal yang diterima, baik keadaan siswa maupun keadaanguru serta proses pembelajaran yang ada.

Lembar kerja siswa dilaksanakan sesuai pokok bahasan yang direncanakan. Lembar kerja siswa dikerjakan secara kelompok dengan dipandu tutor sebayanya siswa mengerjakan dengan benar dan teliti.

Tes formatif, dibuat untuk dilaksanakan dan dikerjakan secara individual, tes formatif dirancang untuk mengetahui sejauh mana kemampuan siswa dalam menyerap dan memahami materi yangdisajikan pada siklus I. Peneliti menyajikan lima soal dalam bentuk essay yang dikemas dalam soal cerita. Diharapkan siswa mampu menyelesaikannya dengan baik, sesuai dengan tujuan yang diharapkan.

\section{Tindakan}

Sesuai dengan urut-urutan proses pembelajaran peneliti menyiapkan dan melaksanakan sesuai dengan urutan sebagai berikut.

Pada proses pembelajaran pada siklus I, peneliti telah menyiapkan beberapa alat peraga yang dibutuhkan. Sesuai pokok bahasan yaitu membaca gambar/denah berskala dan cara menggambar denah berskala. Sebuah gambar/susunan satuan ukuran panjang dan luas dikemas secara baik dan menarik agar siswa lebih antusias mengikuti proses pembelajaran.Masing-masing kelompok diberi alat untuk mengukur halaman sekolah, kemudian menggambarkannya dalam bentuk ukuran yang sebenarnya.

Sebelum proses pembelajaran berlangsung guru perlu meneliti atau mengecek kehadiran siswa untuk mengetahui keaktifan siswa dalam mengikuti proses pembelajaran, kadang dapat membangkitkan semangat siswa apabila sebelum proses pembelajaran diadakan absensi siswa merasa diperhatikan dan diperlukan kehadirannya.

Agar proses pembelajaran berlangsung dengan baik dan kondusif, guru perlu mengingatkan kembali materi pelajaran yang lalu dan bertanya hal- hal yang 
mengarah pada materi pembelajaran. Siswa diberi pertanyaan seputar pokok bahasan yang ada. Misalnya, guru menanyakan tentang berapa luas ruangan kelas. Berapa cm panjang ukuran penggaris yang digunakan dalam pengukuran pada umumnya,dll.

Pada proses pembelajaran berlangsung, banyak metode-metode yang dapat digunakan untuk memperlancar proses pembelajaran, diantaranya adalah ceramah bervariasi. Dalam pokok bahasan membaca gambar atau denah berskala sangat dibutuhkan penjelasan atau ceramah dari guru, tentunya diselingi dengan tanya jawab, demontrasi dan tugas. Maka pada siklusI,diperlukan metode ceramah yang bervariasi agar siswa lebih jelas memahaminya.

Guru telah menyiapkan tugas yang harus dikerjakan siswa secara berkelompok. Tugas dikerjakan di luar kelas untuk mengukur halaman sekolah kemudian menggambarkannya dalam bentuk denah berskala. Hal ini diharapkan agar siswa mengetahui luas halaman sekolahnya yang sebenarnya. Untuk selanjutnya siswa bisa menentukan luas sebenarnya pada gambar atau denah berskala, baik dalam kehidupan nyata maupun dalam soal-soal cerita.

Peran tutor sebaya dalam kelompok kecil ini sangat menentukan sekali. Maka dalam setiap pembentukan kelompok kecil masing-masing dipilih siswa terpandai bertindak sebagai tutor sebaya. Hal ini dimaksudkan agar setiap mengerjakan tugas dengan dipandu tutor sebayanya. Tugas dapat diselesaikan denganbaik.

Guru memberikan kesempatan pada setiap kelompok kecil untuk mengerjakan tugas dengan waktu yang telah ditentukan baik dalam menyiapkan alat-alat pengukuran maupun dalam proses pengukuran di halaman sekolah. Agar hasilnya lebih baik maka setiap kelompok menggunakan kesempatan dengan sebaik-baiknya dan melaksanakan pengukuran dengan baik dan teliti.

Setelah masing-masing kelompok kecil mengerjakan tugasnya dengan baik, kemudian dengan diwakili oleh salah satu anggota kelompok menyampaikan hasil kerja atau mengerjakan di papan tulis, semua siswa memperhatikan dengan seksama, barang kali ada hal-hal yang kurang benar, maka guru sebagai nara sumber sudah menyiapkan beberapa kemungkinan jawaban yang akan ditanyakan oleh anggota kelompok maupun siswalainnya.

Dalam kesempatan ini setelah semua kelompok menyampaikan tugasnya secara berurutan sesuai dengan sub-submateri, guru memberikan kesimpulan dan klasifikasi seandainya ada pemahaman siswa yang perlu diluruskan, guru memberikan kesempatan pula pada siswa barangkali ada hal-hal yang perlu ditanyakan kemudian guru bersama siswa membuat suatu kesimpulan tentang materi yang telahdipelajari.

Setelah proses pembelajaran dilaksanakan, kemudian diadakan tes formatif atau tes akhir pembelajaran pada pokok bahasan membaca gambar atau denah berskala dan menggambar denah berskala secara individual. Hal ini digunakan untuk mengetahui sejauh manapemahaman dan kemampuan siswa secara individual terhadap materi tersebut. Kemudian bersama murid mengoreksi hasil kerja siswa, untuk mengetahui tentang ketuntasan yangdiperoleh. 
Untuk mengakhiri proses pembelajaran guru telah menyiapkan beberapa hal, yaitu bagi siswa yang sudah mendapat nilai yang lebih dari

75 dianggap sudah mencapai ketuntasan dan diberi pengayaan dengan diberi pekerjaan rumah. Sedangkan bagi siswa yang belum mencapai ketuntasan, diberi tugas untuk mengerjakan lagi soal-soal yang belum dijawab secara benar.

\section{Refleksi}

Pada pelaksanaan siklus I masih ditemui banyak kekurangan, diantaranya masih terdapat 11 siswa yang belum dapat menyelesaikan soal dengan baik. Nilai yang diperoleh masih di bawah rata-rata ketuntasan 7,5. Siswa-siswa tersebut masih belum memahami bagaimana cara menyelesaikan soal cerita dengan langkahlangkah yang benar, dan masih belum terampil dalam menghitung dengan menghubungkan antara satuan panjang dan satuan luas. Maka masih diperlukan adanya perbaikan tentang cara menuliskan langkah-langkah menjawab soal cerita dengan benar pada siklus II. Sehingga nilai yang diperoleh sesuai dengan ketuntasan belajar yang diharapkan.

\section{B. Pelaksanaan Siklus II}

1. Perencanaan

Pada siklus ini disampaikan materi tentang cara memecahkan soal cerita tentang membaca gambar atau denah berskala yang dikaitkan dengan kehidupan sehari-hari. Kemudian siswa diberi juga materi tentang cara menafsirkan hasil dari pemecahan soal cerita tentang membaca gambar/denah berskala.

Pada rencana pembelajaran siklus II ini ada dua tujuan yang ingin dicapai setelah proses belajar mengajar selesai dilaksanakan. Yang pertama, setelah siswa memperhatikan pembelajaran guru tentang cara memecahkan soal cerita tentang membaca gambar/denah berskaladengan dipandu dengan tutor sebayanya siswa dapat memecahkan soal cerita tentang membaca gambar atau denah berskala. Yang kedua, setelahsiswa memperhatikan penjelasan guru tentang cara menafsirkan hasil dari pemecahan soal cerita tentang membaca gambar/denah berskala dengan dipandu tutor sebayanya siswa dapat menafsirkan hasil dari pemecahan soal cerita tentang membaca gambar/denah berskala.

Dalam pembentukan kelompok disesuaikan dengan jumlah siswa yang ada. Jumlah siswa dalam penelitian ini ada 19 siswa. Maka setiap kelompok berjumlah 6 orang siswa, ditambah 1 kelompok yang beranggotakan 7 orang siswa. Jadi kelompok kecil yang ada dalam satu kelas terdiri dari tiga kelompok.

Pembentukan kelompok pada siklus II dengan memilih anggota kelompok sesuia nomor urut siswa. Hal ini diharapkan agar siswa tidak merasa bosan belajar bersama anggota kelompoknya sehingga ada variasi dalam mengenal antar individu. Hanya dalam kelompok tersebut tetap dipilih siswa terpandai untuk dijadikan pemandu dalam menyelesaikantugas-tugasnya. Dengan kata lain siswa terpandai dalam kelompok itu berkedudukan sebagai tutor sebaya.

Dalam menyelesaikan soal cerita tidak lagi diharuskan siswa belajar di luar 
kelas, hanya sebagai objek pembelajaran lengkungan sekolah tetap menjadi salah satu pilihan agar siswa dapat lebih mengenal lingkungan sekolah dan sekitarnya serta belajar dengan objek pembelajaran secara konkrit. Selain itu guru juga memberikan contoh-contoh yang mudah dipahami siswa. Dalam menyelesaikan soal cerita ini semua anggota kelompok aktif dalam memecahkan soal cerita yang diberikan guru dan mendiskusikan dalam kelompok dengan dipandu tutor sebayanya. Hasilnya disampaikan dalam bentuk laporan dan salah satu melaporkan di depan kelas.

Dalam kegiatan penelitian tindakan kelas ini,peneliti mengajak teman sejawat sebagai teman atau pengamat penelitian. Hal ini dimaksudkan untuk mengetahui sejauh mana keberhasilan siswa dalam menyelesaikan soal cerita, pada pokok bahasan membaca gambar atau denah berskala dalam kelompok kecil dengan dipandu tutor sebayanya, pengamat bertugas mencatat hal-hal yang diterima, baik keadaan siswa maupun keadaan guru serta proses pembelajaran yang ada.

Lembar kerja siswa dilaksanakan sesuai pokok bahasan yang direncanakan. Lembar kerja siswa dikerjakan secara kelompok dengan dipandu tutor sebayanya siswa mengerjakan dengan benar dan teliti.

Tes formatif, dibuat untuk dilaksanakan dan dikerjakan secara individual, tes formatif dirancang untuk mengetahui sejauh mana kemampuan siswa dalam menyerap dan memahami materi yangdisajikan pada siklus II ini. Peneliti menyajikan lima soal dalam bentuk essay yang dikemas dalam soal cerita. Diharapkan siswa mampu menyelesaikannya dengan baik, sesuai dengan tujuan yang diharapkan.

\section{Tindakan}

Sesuai dengan urut-urutan proses pembelajaran peneliti menyiapkan dan melaksanakan sesuai dengan urutan sebagai berikut.

Pada proses pembelajaran pada siklus II ini, peneliti telah menyiapkan beberapa alat peraga yang dibutuhkan. Sesuai pokok bahasan yaitu cara memecahkan soal cerita tentang membaca gambar/denah berskala dan cara menafsirkan hasil dari pemecahan soal cerita tentang membaca gambar denah berskala.Guru menyajikan sebuah contoh soal cerita yang dikemas dalam bentuk sebuah cerita disertai gambar/denah berskala dan langkah- langkah menyelesaikan soal cerita dengan benar, agar siswa lebih memahami cara-cara menyelesaikan soal cerita dengan lengkah-langkah yang benarpula.

Sebelum proses pembelajaran berlangsung guru perlu meneliti atau mengecek kehadiran siswa untuk mengetahui keaktifan siswa dalam mengikuti proses pembelajaran, dengan selalu diadakan absensi sebelum pelajaran dimulai dapat membangkitkan semangat siswa apabila sebelum proses pembelajaran.

Agar proses pembelajaran berlangsung dengan baik dan kondusif, guru perlu mengingatkan kembali materi pelajaran yang lalu dan bertanya hal- hal yang mengarah pada materi pembelajaran. Siswa diberi pertanyaan seputar pokok bahasan yang ada. Misalnya, guru menanyakan tentang berapa luas halaman sekolah setelah diadakan pengukuran. Mengingatkan kembali tentang urut-urutan satuan ukuran 
panjang danluas.

Pada proses pembelajaran berlangsung, banyak metode-metode yang dapat digunakan untuk memperlancar proses pembelajaran, diantaranya adalah ceramah bervariasi dan demontrasi. Dalam pokok bahasan membaca gambar atau denah berskala sangat dibutuhkan penjelasan atau ceramah dari guru, tentunya diselingi dengan Tanya jawab, demontrasi dan tugas. Maka pada siklus II ini, diperlukan metode ceramah yang bervariasi dan demontrasi agar siswa lebih jelas memahaminya.

Guru telah menyiapkan tugas yang harus dikerjakan siswa secara berkelompok. Tugas dikerjakan di dalam kelas untuk menyelesaikan dan memecahkan soal-soal cerita dengan langkah-langkah yang benar.Lembar kerja ditulis dalam bentuk gambar disertai soal cerita tentang gambar tersebut.

Peran tutor sebaya dalam kelompok kecil ini sangat menentukan sekali. Maka dalam setiap pembentukan kelompok kecil masing-masing dipilih siswa terpandai bertindak sebagai tutor sebaya. Hal ini dimaksudkan agar setiap mengerjakan tugas dengan dipandu tutor sebayanya. Tugas dapat diselesaikan dengan baik.

Guru memberikan kesempatan pada setiap kelompok kecil untuk mengerjakan tugas dengan waktu yang telah ditentukan baik dalam menggambar denah berskala maupun dalam menyelesaikan soal cerita dengan langkah-langkah yang benar. Agar hasilnya lebih baik maka setiap kelompok menggunakan kesempatan dengan sebaikbaiknya dan menyelesaikan pemecahan masalah dengan teliti sesuai dengan langkahlangkah yang sudahdiajarkan.

Setelah masing-masing kelompok kecil mengerjakan tugasnya dengan baik, kemudian dengan diwakili oleh salah satu anggota kelompok menyampaikan hasil kerja atau mengerjakan di papan tulis, semua siswa memperhatikan dengan seksama, barang kali ada hal-hal yang kurang benar, maka guru sebagai nara sumber sudah menyiapkan beberapa kemungkinan jawaban yang akan ditanyakan oleh anggota kelompok maupun siswalainnya.

Dalam kesempatan ini setelah semua kelompok menyampaikan tugasnya secara berurutan sesuai dengan sub-sub materi, guru memberikan kesimpulan dan klasifikasi seandainya ada pemahaman siswa yang perlu diluruskan, guru memberikan kesempatan pula pada siswa barang kali ada hal-hal yang perlu ditanyakan kemudian guru bersama siswa membuat suatu kesimpulan tentang materi yang telah dipelajari.

Setelah proses pembelajaran dilaksanakan, kemudian diadakan tes formatif atau tes akhir pembelajaran pada pokok bahasan membaca gambar atau denah berskala dan menggambar denah berskala secara individual. Hal ini digunakan untuk mengetahui sejauh manapemahaman dan kemampuan siswa secara individual terhadap materi tersebut. Kemudian bersama murid mengoreksi hasil kerja siswa, untuk mengetahui tentang ketuntasan yang diperoleh.

Untuk mengakhiri proses pembelajaran guru telah menyiapkan beberapa hal, yaitu bagi siswa yang sudah mendapat nilai yang lebih dari75 dianggap sudah 
mencapai ketuntasan dan diberi pengayaan dengan diberi pekerjaan rumah. Sedangkan bagi siswa yang belum mencapai ketuntasan, diberi tugas untuk mengerjakan lagi soal-soal yang belum dijawab secara benar.

\section{Refleksi}

Pada pelaksanaan siklus II kemampuan siswa sudah mulai menunjukkan adanya peningkatan, diantaranya tinggal 7 siswa yang belum dapat menyelesaikan soal dengan benar.Siswa-siswa tersebut juga masih belum memahami bagaimana cara menyelesaikan soal cerita dengan langkah-langkah yang benar dan menuliskan hasil yang diperoleh, serta masih belum juga terampil dalam menghitung dengan menghubungkan antara satuan panjang dan satuan luas. Maka masih diperlukan adanya perbaikan tentang menuliskan hasil yang diperoleh dari penyelesaian soal cerita sesuai dengan langkah-langkah yang benar pula pada siklus III. Sehingga nilai yang diperoleh sesuai dengan ketuntasan belajar yang diharapkan.

\section{Pelaksanaan Siklus III}

1. Perencanaan

Pada siklus ini disampaikan materi tentang cara menghitung luas sebenarnya suatu bidang datar pada denah berskala dan cara menghitung luas sebenarnya suatu daerah atau kota pada peta berskala, yang dikaitkan dengan kehidupan sehari-hari. Kemudian siswa diberi juga contoh-contoh cara menghitung jarak sebenarnya antara kota yang satu dengan kota yang lain, dengan menggunakan peta.

Pada rencana pembelajaran siklus III, ada dua tujuan yang ingin dicapai setelah proses belajar mengajar selesai dilaksanakan. Yang pertama, setelah siswa memperhatikan pembelajaran guru tentang cara menghitung luas sebenarnya suatu bidang datar pada denah berskala, dengan dipandu dengan tutor sebayanya siswa dapat menghitung luas sebenarnya suatu bidang datar pada denah berskala. Yang kedua, setelah siswa memperhatikan penjelasan guru tentang cara menghitung luas sebenarnya suatu daerah atau kota pada peta berskala, dengan dipandu tutor sebayanya siswa dapat menghitung luas sebenarnya suatu daerah atau kota pada peta berskala.

Dalam pembentukan kelompok disesuaikan dengan jumlah siswa yang ada. Jumlah siswa dalam penelitian ini ada 19 siswa. Maka setiap kelompok berjumlah 6 orang siswa, ditambah 1 kelompok yang beranggotakan 7 orang siswa. Jadi kelompok kecil yang ada dalam satu kelas terdiri dari tigakelompok.

Pembentukan kelompok pada siklus III dengan memilih anggota kelompok sesuai urutan siswa terpandai satu, dua, dan tiga bertindak sebagai tutor sebaya. Hal ini bertujuan agar siswa terpandai dalam kelas itu dapat membantu masing-masing anggota kelompoknya dalammemimpindan memandu memecahkan masalah serta dapat menyelesaikan soal-soal yang diberikan guru dengan benar.

Untuk lebih mengenal siswa pada objek pembelajaran secara konkret, peneliti mengajak siswa untuk mengamati secara cermat tentang peta dan skalanya. Siswa diberi penjelasan bagaimana cara menghitung jarak antara kota yang satu dengan kota 
yang lain pada peta berskala. Sehingga diharapkan siswa dapat pula menghitung jarak kota sebenarnya. Semua anggota kelompok aktif dalam melaksanakan pengukuran, kemudian mendiskusikan dalam kelompoknya dengan dipandu tutor sebayanya. Hasilnya disampaikan dalam bentuk laporan atau salah satu melaporkan di depan kelas.

Dalam kegiatan penelitian tindakan kelas ini, peneliti mengajak teman sejawat sebagai teman atau pengamat penelitian. Hal ini dimaksudkan untuk mengetahui sejauh mana keberhasilan siswa dalam menyelesaikan soal cerita, pada pokok bahasan membaca gambar atau denah berskala dalam kelompok kecil dengan dipandu tutor sebayanya, pengamat bertugas mencatat hal-hal yang diterima, baik keadaan siswa maupun keadaan guru serta proses pembelajaran yang ada.

Lembar kerja siswa dilaksanakan sesuai pokok bahasan yang direncanakan. Lembar kerja siswa dikerjakan secara kelompok dengan dipandu tutor sebayanya siswa mengerjakan dengan benar dan teliti.

Tes formatif, dibuat untuk dilaksanakan dan dikerjakan secara individual, tes formatif dirancang untuk mengetahui sejauh mana kemampuan siswa dalam menyerap dan memahami materi yangdisajikan pada siklus III. Peneliti menyajikan lima soal dalam bentuk essay yang dikemas dalam soal cerita. Diharapkan siswa mampu menyelesaikannya dengan benar, sesuai dengan tujuan yang diharapkan.

\section{Tindakan}

Sesuai dengan urut-urutan proses pembelajaran peneliti menyiapkan dan melaksanakan sesuai dengan urutan sebagai berikut.

Pada proses pembelajaran pada siklus III, peneliti telah menyiapkan beberapa alat peraga yang dibutuhkan. Sesuai pokok bahasan yaitu cara menghitung luas sebenarnya suatu bidang datar pada denah berskala. dn cara menghitung luas sebenarnya suatu daerah atau kota pada peta berskala. Dengan menyajikan beberapa peta berskala, guru memberikan pejelasan cara menghitung luas pada peta dan luas sebenarnya. Diharapkan siswa akan lebih antusias dalam mengikuti proses pembelajaran.

Sebelum proses pembelajaran berlangsung guru perlu meneliti atau mengecek kehadiran siswa untuk mengetahui keaktifan siswa dalammengikuti proses pembelajaran, kadang dapat membangkitkan semangat siswa apabila sebelum proses pembelajaran diadakan absensi siswa merasa diperhatikan dan diperlukan kehadirannya.

Agar proses pembelajaran berlangsung dengan baik dan kondusif, guru perlu mengingatkan kembali materi pelajaran yang lalu dan bertanya hal- hal yang mengarah pada materi pembelajaran. Siswa diberi pertanyaan seputar pokok bahasan yang ada. Misalnya, guru menanyakan tentang berapa luas daerah Kabupaten Barito Selatan? Berapa jarak kota Buntok dan Palangkaraya?

Pada proses pembelajaran berlangsung, banyak metode-metode yang dapat digunakan untuk memperlancar proses pembelajaran, diantaranya adalah ceramah 
bervariasi. Dalam materi menghitung luas sebenarnya suatu bidang datar pada denah berskala dan menghitung luas sebenarnya suatu daerah atau kota pada peta berskala, sangat dibutuhkan penjelasan atau ceramah dari guru,tentunya diselingi dengan Tanya jawab,demontrasi dan tugas. Maka pada siklus III, diperlukan metode ceramah yang bervariasi agar siswa lebih jelas memahaminya.

Guru telah menyiapkan tugas yang harus dikerjakan siswa secara berkelompok. Tugas dikerjakan di dalam kelas untuk menghitung luassebenarnya suatu bidang datar pada denah berskala dan menghitung luas sebenarnya suatu daerah atau kota pada peta berskala. Hal ini diharapkan agar siswa mengetahui luas atau jarak sebenarnya yang disajikan dalam bentuk gambar atau peta.

Peran tutor sebaya dalam kelompok kecil ini sangat menentukan sekali. Maka dalam setiap pembentukan kelompok kecil masing-masing dipilih siswa terpandai bertindak sebagai tutor sebaya. Hal ini dimaksudkan agar setiap mengerjakan tugas dengan dipandu tutor sebayanya. Tugas dapat diselesaikan dengan baik.

Guru memberikan kesempatan pada setiap kelompok kecil untuk mengerjakan tugas dengan waktu yang telah ditentukan baik dalam menyiapkan alat-alat pengukuran maupun dalam proses penyelesaian tugas. Agar hasilnya lebih baik maka setiap kelompok menggunakan kesempatan dengan sebaik-baiknya dan melaksanakan pengukuran dengan baik dan teliti.

Setelah masing-masing kelompok kecil mengerjakan tugasnya dengan baik, kemudian dengan diwakili oleh salah satu anggota kelompok menyampaikan hasil kerja atau mengerjakan di papan tulis, semua siswa memperhatikan dengan seksama,barangkali ada hal-hal yang kurang benar, maka guru sebagai nara sumber sudah menyiapkan beberapa kemungkinan jawaban yang akan ditanyakan oleh anggota kelompok maupun siswa lainnya.

Dalam kesempatan ini setelah semua kelompok menyampaikan tugasnya secara berurutan sesuai dengan sub-sub materi, guru memberikan kesimpulan dan klasifikasi seandainya ada pemahaman siswa yang perlu diluruskan, guru memberikan kesempatan pula pada siswa barangkaliada hal-hal yang perlu ditanyakan kemudian guru bersama siswa membuat suatu kesimpulan tentang materi yang telah dipelajari.

Setelah proses pembelajaran dilaksanakan, kemudian diadakan tes formatif atau tes akhir pembelajaran pada materi menghitung luas sebenarnya suatu bidang datar pada denah berskala dan menghitung luas sebenarnya suatu daerah atau kota pada peta berskala. Hal ini digunakan untuk mengetahui sejauh mana pemahaman dan kemampuan siswa secara individual terhadap materi tersebut. Kemudian bersama murid mengoreksi hasil kerja siswa, untuk mengetahui tentang ketuntasan yang diperoleh.

Untuk mengakhiri proses pembelajaran guru telah menyiapkan beberapa hal, yaitu bagi siswa yang sudah mendapat nilai yang lebih dari 75 dianggap sudah mencapai ketuntasan dan diberi pengayaan dengan diberi pekerjaan rumah. Sedangkan bagi siswa yang belum mencapai ketuntasan, diberi tugas untuk 
mengerjakan lagi soal-soal yang belum dijawab secara benar.

\section{Refleksi}

Pada pelaksanaan siklus III sudah menunjukkan keadaan yang baik, tinggal 4 orang siswa saja yang bernilai kurang. Keadaan tersebut sudah menunjukkan adanya perubahan proses pembelajaran matematika yang diharapkan. Hanya siswa-siswa tersebut yang masih belum memahami bagaimana cara menyelesaikan soal cerita dengan langkah-langkah yang benar, dan masih belum terampil dalam menghitung dengan menghubungkan antara satuan panjang dan satuan luas, bisa diberikan suatu perhatian secara khusus. Maka pada siklus III inilah sesuai dengan hal yang diperoleh mencapai rata-rata 8,11 sudah menunjukkan adanya ketuntasan belajar yang diharapkan. Untuk itu tidak diperlukan lagi adanya perbaikan pada siklus berikutnya.

\section{Pembahasan}

Pada siklus I disampaikan materi tentang cara membaca gambar atau denah berskala yang dikaitkan dengan kehidupan sehari-hari. Terlebih dahulu siswa diingatkan kembali tentang satuan ukuran panjang dan satuan ukuran luas. Namun karena keterbatasan siswa dalam memahami konsep tentang satuan ukuran panjang dan luas. Sehingga pada saat pembelajaran berlangsung banyak siswa yang masih mengalami kesulitan untuk menerapkan satuan ukuran panjang dan satuan luas pada materi membaca gambar atau denah berskala (perbandingan skala). Respon siswa masih kurang, belum menunjukkan adanya minat terhadap materi tersebut. Sehingga hasil yang diperoleh masi sangat kurang, masih di bawah 50\%. Diterapkannya model pembelajaran tutor sebaya dalam kelompok kecil,yaitu dengan memanfaatkan anakanak pandai diantara kelompoknya untuk memandu dalam menyelesaikan tugas, serta membawa siswa untuk mempelajari materi dengan benda-benda konkret sebagai objek pembelajaran. Anak dibawa ke luar kelas untuk mengukur luas halaman sekolah dan menggambarkannya dalam bentuk gambar atau denahberskala.

Berdasarkan hasil tes yang diperoleh pada siklus I terdapat 11 siswa yang mendapat nilai kurang dari 6,5, rata-rata nilainya 6,32. Sedangkan ketuntansan belajarnya baru mencapai $42 \%$, kenyataan itu menunjukkan hasil pembejaran masih sangat rendah. Dilihat dari hasil tes 8 siswa yang mendapat nilai rendah, hal ini disebabkan mereka belum memahami benar cara menyelesaikan soal cerita tentang membaca gambar atau denah berskala. Di samping itu kehidupan dunia pendidikan di lingkungan tempat tinggal mereka masih membutuhkan orang-orang yang mampu mendorong agar mereka sadar akan manfaat pendidikan yang sebenarnya dan lebih maju.

Sebagai perbaikan pada pelaksanakan siklus I adalah siklus II, pada pelaksanaan siklus II disampaikan materi mengenai cara memecahkan soalcerita tentang membaca gambar atau denah berskala dan cara menafsirkan hasil dari pemecahan soal cerita tentang membaca gambar atau denah berskala.Dikarenakan nilai yang dihasilkan pada siklus I masih ditemui siswa yang mendapat nilai kurang dan kesulitan dalam memahami materi pelajaran. Dengan demikian pelaksanakan 
pembelajaran pada siklus II, ditekankan pada langkah-langkah menyelesaikan soal cerita tentang membaca gambar atau denah berskala dengan benar. Sehingga diharapkan siswa akan lebih materi pelajaran, serta lebih mudah mengerjakan tes akhir pembelajaran, dengan nilai yang lebih baik.

Pada pelaksanaan siklus II, terdapat 7 siswa yang mendapat nilai kurang dari 6,5, sedangkan yang mendapat nilai lebih dari 6,5 adalah 12 siswa. Tingkat ketuntasan yang diperoleh sudah mencapai 63\%. Sedangkan rata-rata nilai yang diperoleh 7,26. Dengan demikian tingkat keberhasilan siswa sudah cukup meningkat. Oleh karena itu pelaksanakan penelitian tindakan dan perbaikanpada siklusIII.

Pelaksanaan perbaikan pada siklus III disampaikan materi cara menghitung luas sebenarnya suatu bidang datar pada gambar atau denah berskala dan cara menghitung luas sebenarnya suatu daerah atau kota pada peta berskala. Pelaksanakan proses pembelajaran pada siklus II sudah cukup kondusif, siswa sudah lebih memahami materi pelajaran yang diberikan guru. Dikarenakan sebelum proses pembelajaran berlangsung siswa telah diberi perbaikan bagi yang bernilai kurang, sedangkan yang bernilai lebih diberi pengayaan. Sedangkan untuk lebih menguasai materi pelajaran, diadakan apersepsi sebagai pengulangan materi sebelumnya. Dengan demikian pelaksanaan pembelajaran pada sklus III ini sebagian besar siswa sudah memahami materi yang diberikanguru

Pada pelaksanaan siklus III, tinggal 4 siswa yang memperoleh nilai kurang dari 6,5, sedangkan 15 siswa memperoleh nilai lebih dari 6,5, rata-rata nilai yang diperoleh dalam siklus III adalah 8,11, dan tingkat ketuntasan yang diperoleh telah mencapai $79 \%$. Sehingga keberhasilan siswa dalam proses pembelajaran dengan model pembelajaran tutor sebaya dalam kelompok kecil dalam pokok bahasan menyelesaikan soal cerita tentang membaca gambar atau denah berskala telah mencapai ketuntasan. Dengan demikian, hipotesis tindakan penelitian ini dapat diterima.

\section{Kesimpulan}

Berdasarkan hasil penelitian dapat disimpulkan bahwa melalui model pembelajaran tutor sebaya dalam kelompok kecil, kemampuan siswa dalam mengemukakan pendapat dan bekeja sama dalam setiap kelompoknya dapat ditingkatkan. Selain itu peran tutor sebaya merupakan teman bekerja sekaligus teman belajar sehingga dapat menambah keberanian siswa dalam bertanya, dan mengerjakan tugas guru di depan kelas. Serta ketrampilan siswa dalam menyelesaikan soal cerita menunjukkan kemajuan yang cukup baik. Sehingga hasil belajar siswa mengalami peningkatan. Berdasarkan penelitian bahwa hasil belajar yang diperoleh siswa kelas VI SD Negeri 1 Teluk Betung Kecamatan Karau Kualatahun pelajaran 2018/2019 pada pokok bahasan membaca gambar atau denah berskala nilai rata-ratanya meningkat menjadi berkisar 8,11. 


\section{Bibliografi}

Aji, Mukti, M. 1997. Matematika Sekolah Untuk Kelas VI. Jakarta: PT. Intan Pariwara.

Bruner, Jerome. 2004. Materi Pelatihan Terintegrasi. Jakarta: Dirjen Depdiknas.

Depdikbud. 1994. Kurikulum Pendidikan Dasar. Garis-Garis Besar Program Pengajaran Kelas VI SD. Jakarta: Depdikbud.

Depdikbud.1999/2000.PetunjukPelaksanaanKegiatanBelajarMengajarKelas

Sekolah Dasar. Jakarta:Depdikbud.

Depdikbud. 1998. Pedoman Pembinaan Profesional Guru Sekolah Dasar dan Menengah. Jakarta: Depdikbud.

Depdiknas. 2004. Matematika-Materi Pelaihan Terintegrasi. Jakarta: Dirgen Pendasmen.

Drost, JPastor (dalam Achmad Kereng). 2003. Tenaga Kependidikan Profesional Menghadapi Tantangan. Jakarta: Suara Guru7-9.

Kereng, Achmad. 2003. Tenaga Kependidikan Profesional Menghadapi Tantangan. Jakarta: Suara Guru 7-9.

Kereng,Achmad(dalamDjokoWaludi).2003.TenagaKependidikanProfesional Menghadapi Tantangan. Jakarta: Suara Guru7-9.

Natawijaya, Rochman. 1984. Pengajaran Remedial. Jakarta: Depdikbud.

Oemar,Hamalik.2001.ProsesBelajarMengajar.Jakarta:PT.BumiAksara.

Rahayu Hadinoto, Siti (dalam Achmad Kereng). 2003. Tenaga Kependidikan Profesional Menghadapi Tantangan. Jakarta: Suara Guru 7-9

Sunarto. 1984. Perkembangan Peserta Didik. Jakarta: Depdikbud.

Suyitno, Amin. 2004. Dasar-dasar dan Proses Pembelajaran Matemaika I. Bahan Ajar Program S1 Pendidikan Matematika Konsrentrasi Pendidikan Dasar. Semarang: UNNES.

Suyitno, Amin. 2004. Petunjuk Penulisan Karya Ilmiah Remaja. Semarang. 
Upaya Meningkatkan Hasil Belajar Siswa Kelas Vi Sd Negeri 1 Teluk Betung

Dalam Menyelesaikan Soal Cerit

Sulardi. 1999. Pandai Berhitung Matematika. Suplemen Garis-Garis Besar Program Pengajajaran 1999. Jakarta: PT. Erlangga.

Zaini, Hisyam (dalam Suyitno, Amin). 2002. Model Pembelajaran Tutor Sebaya dalam Kelompok Kecil. Semarang: UNNES 